Archives of Agriculture and Environmental Science

\title{
Screening of wheat (Triticum aestivum L.) lines against salinity under field condition
}

\author{
S. Banik ${ }^{1}$, S. Biswas ${ }^{2}$, F.H. Bipasha ${ }^{3}$, F. Haque ${ }^{4}$, M. Morshed ${ }^{5^{*}}$ (D) , M.S. Rahman ${ }^{6}$ and S.K. Singh ${ }^{7}$ \\ ${ }^{1}$ Department of Genetics \& Plant Breeding, Patuakhali Science and Technology University, Patuakhali, BANGLADESH \\ ${ }^{2}$ Department of Horticulture, Bangabandhu Sheikh Mujibur Rahman Agricultural University, Gazipur-1706, BANGLADESH \\ ${ }^{3}$ Bangladesh Agricultural University, Mymensingh-2202, BANGLADESH \\ 4,5 Department of Soil Science, Bangabandhu Sheikh Mujibur Rahman Agricultural University, Gazipur-1706, BANGLADESH \\ ${ }^{6}$ Scientific Officer, Regional Agricultural Research Station, Agricultural Research Institute (BARI), Moulovibazar, BANGLADESH \\ ${ }^{7}$ Department of Biochemistry, Sher-e-Bangla Agricultural University, Dhaka, BANGLADESH \\ *Corresponding author's E-mail: mmorshed3012@gmail.com
}

\section{ARTICLE HISTORY}

Received: 07 February 2019

Revised received: 26 February 2019

Accepted: 03 March 2019

\section{Keywords}

Phenotypic and Genotypic co-efficient Salinity

Wheat (Triticum aestivum L.)

Wheat lines

\begin{abstract}
An experiment was undertaken in order to screening wheat genotypes against salinity under field condition with 14 wheat genotypes including 6 check varieties. The genotypes were tested in saline soil where the salinity of the experimental field ranges from 1.5 to $10.3 \mathrm{dS} / \mathrm{m}$ during the cropping period. Analysis of variance revealed significant variation among the genotypes for all characters. Phenotypic and Genotypic co-efficient of variation was low for almost all the characters. Phenotypic co-efficient of variation ranged from 8.42 to 23.45 for plant height and yield respectively, while the highest genotypic coefficient of variation (18.90) was observed in yield and lowest (6.83) was found in seed per spike. All of the trait exhibited moderate to high heritability in broad sense ( $\mathrm{h} 2 \mathrm{~b}$ ) coupled with a wide range of genetic advance and genetic advance in percentage of mean. Heritability ranged from 37.64 to 91.14 for seed per spike and thousand seed weight respectively. Yield had significant positive correlation with spike length, spikelet per spike, seed per spike, thousand seed weight. On the other hand, yield was found to show a positive relationship with tiller per plant. Tiller per Plant, spikelet per spike, 1000 seed weight were responsible for reduction of yield per plant indirectly. Yield ranged from 1.14 ton/ha to 2.1 ton/ha. The present research work clearly demonstrated that based on field performance considering yield, the genotypes BARI Gom 25 and BARI Gom 26 is best and other some genotypes BAW 1182, BAW 1177 respectively showed their most effective performance on saline soil.
\end{abstract}

(C)2019 Agriculture and Environmental Science Academy

Citation of this article: Banik, S., Biswas, S., Bipasha, F.H., Haque, F., Morshed, M., Rahman, M.S. and Singh, S.K. (2019). Screening of wheat (Triticum aestivum L.) lines against salinity under field condition. Archives of Agriculture and Environmental Science, 4(1): 88-95, https://dx.doi.org/10.26832/24566632.2019.0401014

\section{INTRODUCTION}

Wheat (Triticum aestivum L.) is second after rice as a source of calories in the diets of consumers in developing countries and is the first as a source of protein (Braun et al., 2010). Wheat is an especially critical "stuff of life" for the approximately 1.2 billion "wheat dependent" to 2.5 billion "wheat-consuming" poor-men, women and children-who live on less than \$US 2/day (FAOSTAT, 2010). The International Food Policy Research Institute (IFPRI, 1997) projections indicate that the world demand for wheat will rise from 552 million tons in 1993 to 775 million tons by 2020 , and $60 \%$ in total by 2050 (IFPRI, 1997). Total production of wheat in the whole world mainly depends on two modern species: common or hexaploid bread wheat (Triticum aestivum, $2 n=6 x=42$, AABBDD) and durum or tetraploid wheat ( $T$. turgidum subsp. durum, $2 n=4 x=28$, AABB). Though wheat has been classified as a salt tolerance plant, the response of different wheat cultivars to environmental stress and various types of target environments are not the same. Breeding for improved salinity tolerance (ST) is the only feasible way of improving yield in saline soil (Genc et al., 2007). Soil salinity is the major stress that plant face among all other stresses which 
is associated with arid and semi-arid areas of the world (Ashraf and $\mathrm{Wu}, 1994)$. Salinity is a worldwide problem and total salt affected area in the world is about $955 \mathrm{~m}$ ha. This problem is also very serious in dry season because $6.67 \mathrm{~m}$ ha of arable land in are affected by various degrees of soil salinity. Exploiting the genetic potential of crop plants could be a serious approach to deal with the soil salinity for their adaptability to adverse soil conditions. And this strategy is a short term and enhances the crop cultivation on the salt affected fields. That's why the screening of salt tolerant genotypes is necessary. Richards et al. (1987) suggested that improvement for salt tolerance might be achieved through selection from existing wheat varieties.

Because of the huge spatial and temporal variability in soil salinity under field conditions screening of many genotypes is not possible (Richards, 1983). Therefore, the crop gene stocks are often screened in nutrient solution by adding appropriate amount of salt to develop the desired salinity levels. This method is comparatively quicker and more reliable than others for screening the genotypes against salinity condition. Filed screening of large numbers of cultivar or line for salinity tolerance is very difficult. Therefore, a multiphase screening method consisting of sequential or parallel various laboratory and field studies have been proposed by Houshmand et al. (2005). Some researchers believe that breeding and selection should focus on increasing yield capacity. Consequently, when high yielding cultivars planted in low or moderate saline conditions the yield become more than saline resistance cultivar. High grain yield under salinity stress was found to be a better criterion for salt tolerance than biomass, harvest index, or relative salt tolerance. However, low yielding varieties may be less sensitive to salinity than high-yielding cultivars. Therefore, the development of saline tolerant genotypes of wheat is the need of the day. Keeping this in view, the present study was therefore, designed to genetic basis of grain yield components and develops a suitable selection criterion for future wheat breeding program. With conceiving the above scheme and discussion in mind, the present research work has been undertaken in order to screen the wheat genotypes against saline soil under field condition to assess their yield performance, to identify saline tolerant genotypes of wheat and increase wheat areas and production by developing salt resistant varieties under field condition and to estimate the genetic variability and character association among of genotypes of wheat (T. aestivum).

\section{MATERIALS AND METHODS}

\section{Site, soil and climate}

The research was conducted at farmer's field at Kuakata, Kalapara, Patuakhali under on-farm Research Division, Bangladesh Agricultural Research Institute, Patuakhali. The area is under Agro ecological Zone (AEZ) -13 named Gangetic Tidal Floodplains. The area lies at 0.9 to 2.1 meter above mean sea level (Iftekhar and Islam, 2004). This zone occupies considerable areas of coastal saline lands of Patuakhali district. Soil characteristics of the coastal zone are silty loams or alluvium. The soil of the experimental plot was loamy in texture and it was medium high land and belonging to the tidal flood plain. The organic matter content was low $(0.93 \%)$ in most cases. Generally, Patuakhali region falls under the sub-tropical climate which is characterized by high temperature and humidity, heavy rainfall with occasional gusty winds in the month of April to September and less rainfall associated with moderately low temperature during October to March.

\section{Experimental design}

The experiment was laid out in Randomized Complete Block Design (RCBD) with four replications. The whole field was divided into four blocks and each block consisted of fourteen plots. The replications were separated from one another by $1 \mathrm{~m}$. The distance between plots was $50 \mathrm{~cm}$. The treatment was randomly assigned to each of the block. Plot size for genotype was $2.5 \mathrm{~m} \times 0.8 \mathrm{~m}$. and four rows consist a plot. A total of 14 wheat genotypes were used in this experiment (Table 1). Among the materials, 6 check variety and rest are lines, all genotypes collected from Wheat Research Center (WRC), BARI, Gazipur.

Table 1. Used plant genotype on experiment is given below.

\begin{tabular}{llll}
\hline S.N. & Genotype & Type & Source \\
\hline 1 & BARI Gom-25 & Released variety & WRC \\
2 & BARI Gom 26 & Released variety & WRC \\
3 & BARI Gom 27 & Released variety & WRC \\
4 & BARI Gom 28 & Released variety & WRC \\
5 & BARI Gom 29 & Released variety & WRC \\
6 & BARI Gom 30 & Released variety & WRC \\
7 & BAW 1135 & Advance line & WRC \\
8 & BAW 1157 & Advance line & WRC \\
9 & BAW 1170 & Advance line & WRC \\
10 & BAW 1177 & Advance line & WRC \\
11 & BAW 1182 & Advance line & WRC \\
12 & BAW 1193 & Advance line & WRC \\
13 & BAW 1200 & Advance line & Advance line \\
\hline
\end{tabular}


Collection of data

Data were collected on different parameters such as plant height $(\mathrm{cm})$, number of tiller per plant, spike length $(\mathrm{cm})$, spikelet per spike, seed per spike, thousand seed weight(g), yield of $T$. estivum per plot etc. All the grains from the main stem and tiller were gathered together and its weight was taken as yield per plant the 1000 grain weight $(\mathrm{g})$ of T. aestivum were taken and converted it into ton/hectare using the following formula:

Grain yield $(t / h a)=$ Field weight $\times 0.8 \times(10000) /$ Area $\times$ $(100-\mathrm{MC}) / 85$

Adjusted yield $=\mathrm{CF} \times$ Plot yield

$$
\mathrm{CF}=\frac{\mathrm{M}-0.3 \times \mathrm{N}}{\text { Harvested plant }}
$$

Where, $M=$ Total number of plant in the plot and $N=$ Missing plant

\section{Statistical analysis}

The collected data on various parameters were statistically analyzed to find out the statistical significance of the experimental results. Analysis of variance was done for all the characters under study using the mean values (Singh and Chaudhury, 1985). The significance of the difference between treatment means was evaluated by the Least Significance Difference (LSD) test for the interpretation of the results (Gomez and Gomez, 1984).

Estimation of genetic parameters

The following formulas were used in the calculation (Table 2).

Table 2. List of formulas used in the calculation of genetic parameters.

\begin{tabular}{|c|c|c|}
\hline Genetic parameters & Abbreviation/unit & Formula \\
\hline Genotypic variance & $\sigma_{\mathrm{g}}^{2}$ & $\sigma_{\mathrm{g}}^{2}=\frac{\text { GMS-EMS }}{\mathrm{r}}$ \\
\hline Phenotypic variance & $\sigma_{\mathrm{ph}}^{2}$ & $\sigma_{\mathrm{ph}}^{2}=\sigma_{\mathrm{g}}^{2}+\mathrm{EMS}$ \\
\hline Genotypic co-efficient of variation & GCV & $\mathrm{GCV}(\%)=\frac{\sqrt{\sigma_{\mathrm{E}}^{2}}}{\overline{\mathrm{x}}} \times 100$ \\
\hline phenotypic co-efficient of variation & PCV & $\operatorname{PCV}(\%)=\frac{\sqrt{\sigma_{\mathrm{ph}}^{2}}}{\overline{\mathrm{x}}} \times 100$ \\
\hline Heritability & $h_{b}^{2}$ & $\left(h_{b}^{2}\right)=\frac{\sigma_{g}^{2}}{\sigma_{p h}^{2}} \times 100$ \\
\hline Genetic advance & GA & $(\mathrm{GA})=\frac{\sigma_{\mathrm{g}}^{2}}{\sigma_{\mathrm{ph}}^{2}} \times \mathrm{k} \times \sigma_{\mathrm{ph}}$ \\
\hline Genetic advance in percent of mean & $\mathrm{GA} \%$ & $(\mathrm{GA} \%)=\frac{\mathrm{GA}}{\overline{\mathrm{x}}} \times 100$ \\
\hline Genotypic correlation coefficient & $\mathrm{r}_{\mathrm{g}}$ & $\mathrm{r}_{\mathrm{g}}=\frac{\operatorname{Cov}_{(\mathrm{g} 1.2}}{\sqrt{\sigma_{(\mathrm{g} 1}^{2} \sigma_{(\mathrm{g})}^{2}}}$ \\
\hline phenotypic correlation co-efficient & $\mathrm{r}_{\mathrm{ph}}$ & $\mathrm{r}_{\mathrm{ph}}=\frac{\operatorname{Cov}_{(\mathrm{ph}) 122}}{\sqrt{\sigma_{(\mathrm{ph}) 1}^{2} \sigma_{(\mathrm{ph} / 2}^{2}}}$ \\
\hline
\end{tabular}

Note: $\mathrm{GMS}=$ Genotypic mean square, EMS = Error mean square, $\mathrm{r}=$ Number of replication, $\overline{\mathrm{x}}=$ Population mean, $\mathrm{k}=$ selection intensity, $\mathrm{Cov}_{(\mathrm{g}) 1.2}=$ Genotypic covariance between the variable $X_{1}$ and $X_{2}, \operatorname{Cov}_{(\mathrm{ph}) 1.2}=$ Phenotypic covariance between the variable $X_{1}$ and $X_{2}$. 


\section{RESULTS AND DISCUSSION}

Mean performance of check and advance line

\section{Plant height}

The maximum plant height was observed in BARI Gom-25 $(76.85 \mathrm{~cm})$ followed by BARI Gom $28(74.04 \mathrm{~cm})$, BAW 1182 $(72.92 \mathrm{~cm})$ and BAW $1200(72.11 \mathrm{~cm})$ and minimum plant height was observed in BARI Gom $30(58.88 \mathrm{~cm})$ followed by BAW $1157(63.0 \mathrm{~cm})$ and BAW $1193(63.51 \mathrm{~cm})($ Table 3). From these above results we can conclude that check variety found highest plant height compare to advance line. Many investigators determined the associations among different characters in wheat (T. aestivum). Moursi et al. (1975) mentioned that number of tiller per plant, plant height and 1000 seed weight had consistent positive and significant correlations with yield.

\section{Number of tiller per plant}

Number of tiller significantly varied among the treatment. Maximum number of tiller was found in BARI Gom-25 (2.81) followed by BAW 1193(2.26) and BAW 1182(2.21). And minimum number of tiller was found in BAW 1170 (1.27) followed by BAW 1202 (1.44) (Table 3). In this parameter also check variety showed better tillering capacity than the advance line. These results were in consistent with those of Chowdhury and Islam (1993) who also observed variable - plant heights, tiller per plant of different wheat cultivars/lines.

\section{Spike length}

In case of spike length of T. aestivum found not much significant variation among the treatment. Maximum spike length was found in BAW $1177(8.26 \mathrm{~cm})$ followed by BAW $1182(8.03 \mathrm{~cm})$ and minimum was observed in BAW $1170(5.87 \mathrm{~cm})$ followed by BARI Gom $29(5.93 \mathrm{~cm})$ (Table 3).
Number of spikelet's/spike

Number of spikelets/spike of T. aestivum was significantly varied from at final harvest among the treatments. The maximum spikelets/spike was observed in BARI Gom-25 (10.61) followed by BAW 1157 (10.39), BARI Gom 27 (9.9), BARI Gom 28 (9.86). And minimum spikelets/spike was observed in BARI Gom 29 (8.37) followed by BARI Gom 30 (8.43) (Table 3).

\section{Seed/spike}

In case of seed/spike of T. aestivum maximum number of seed/ spike was found in BARI Gom-25 (27.25) followed by BAW 1182 (26.88), BARI Gom 26 (26.73), BARI Gom 28 (25.6) and BARI Gom 29 (25.20). Minimum seed/spike was found in BARI Gom 30 (20.88) followed by BAW 1202 (21.76) and BAW 1200 (22.5) (Table 3). From these above results we can conclude that check variety found maximum and minimum (seed/spike) compare to advance line (Figure 1). Mohammedein and Idris (2017) found positive and significant correlation between yield and each of plant height, number of tiller per plant, number of seed per spike and thousand seed weight and emphasized the role of these traits in selection of high yield in wheat.

\section{Weight of 1000 seeds}

The weight of 1000 seeds of T. aestivum was significantly varied among the treatment. Maximum 1000 seed weight was found in BAW 1182 (45.39g) which was followed by BARI Gom-25 (43.38g) (Table 3). And minimum was found I BARI Gom 30 (31.13g). In case of 1000 seed I found advance line showed better seed weight than check although both BAW 1182 and BARI Gom-25 show statistically similar results. El-Shouny et al. (2005) and Akhtar (2001) identified different traits like spike length, spikelet per spike, seed per spikelet, 1000-seed weight as potential selection criteria in breeding programs aiming at higher yield.

Table 3. Mean performance of wheat genotype in respect of plant height, number of tiller per plant, spike length, spikelets per spike, seed per spike, 1000 seed weight and yield.

\begin{tabular}{|c|c|c|c|c|c|c|c|}
\hline Genotype & Plant height & Tiller/plant & Spike length & $\begin{array}{l}\text { Spikelets/ } \\
\text { spike }\end{array}$ & Seed/spike & $\begin{array}{c}1000 \text { seed } \\
\text { weight }\end{array}$ & $\begin{array}{l}\text { Yield } \\
\text { (t/ha) }\end{array}$ \\
\hline BARI Gom-25 & $76.85 a$ & $2.813 \mathrm{a}$ & 7.488 a-d & $10.61 \mathrm{a}$ & $27.25 \mathrm{a}$ & $43.38 \mathrm{a}$ & $2.175 \mathrm{a}$ \\
\hline BARI Gom 26 & $65.85 \mathrm{de}$ & $2.033 \mathrm{~b}-\mathrm{d}$ & $7.012 \mathrm{a}-\mathrm{d}$ & 9.250 c-e & $26.73 a b$ & 37.96 bc & $1.913 a b$ \\
\hline BARI Gom 27 & $70.46 b-d$ & 1.987 b-d & $7.463 \mathrm{a}-\mathrm{d}$ & 9.988 a-c & 24.14 b-e & $35.66 \mathrm{~cd}$ & $1.300 \mathrm{~cd}$ \\
\hline BARI Gom 28 & $74.04 \mathrm{ab}$ & 2.058 b-d & 7.438 a-d & $9.863 \mathrm{a}-\mathrm{c}$ & 25.67 a-d & $36.83 \mathrm{~cd}$ & $1.493 \mathrm{~cd}$ \\
\hline BARI Gom 29 & 67.19c-e & 2.088 b-d & $5.930 \mathrm{~cd}$ & $8.375 \mathrm{e}$ & 25.20 a-d & $37.90 \mathrm{~b}-\mathrm{d}$ & $1.360 \mathrm{~cd}$ \\
\hline BARI Gom 30 & $58.88 \mathrm{f}$ & 1.577 c-e & $6.270 \mathrm{~b}-\mathrm{d}$ & 8.432 e & $20.88 \mathrm{f}$ & $31.13 \mathrm{e}$ & $1.140 \mathrm{~d}$ \\
\hline BAW 1135 & $70.82 b-d$ & 1.883 b-e & $6.912 \mathrm{a}-\mathrm{d}$ & $8.613 \mathrm{de}$ & 23.85 c-e & $35.00 \mathrm{~d}$ & $1.280 \mathrm{~cd}$ \\
\hline BAW 1157 & 63.08 ef & 1.992 b-d & $6.813 \mathrm{a}-\mathrm{d}$ & 10.39 a-c & 23.83 c-e & $37.53 \mathrm{~b}-\mathrm{d}$ & $1.418 \mathrm{~cd}$ \\
\hline BAW 1170 & $70.46 \mathrm{bcd}$ & $1.270 \mathrm{e}$ & $5.875 \mathrm{~d}$ & 9.738 a-d & 24.14 c-e & 38.33 bc & $1.168 \mathrm{~d}$ \\
\hline BAW 1177 & $64.35 \mathrm{e}$ & $2.370 \mathrm{ab}$ & $8.262 \mathrm{a}$ & $10.76 \mathrm{a}$ & 26.44 a-c & $40.33 b$ & $1.425 \mathrm{~cd}$ \\
\hline BAW 1182 & $72.92 \mathrm{ab}$ & $2.210 \mathrm{a}-\mathrm{c}$ & $8.030 \mathrm{a}$ & $10.55 \mathrm{ab}$ & $26.88 a$ & $45.39 a$ & $1.622 \mathrm{bc}$ \\
\hline BAW 1193 & $63.51 \mathrm{ef}$ & $2.263 \mathrm{ab}$ & $7.507 \mathrm{a}-\mathrm{c}$ & 9.215 c-e & $23.17 \mathrm{~d}-\mathrm{f}$ & $37.16 \mathrm{~cd}$ & $1.388 \mathrm{~cd}$ \\
\hline BAW 1200 & 72.11abc & $2.013 \mathrm{~b}-\mathrm{d}$ & $7.662 a b$ & 9.825 a-c & 22.50 ef & $37.33 \mathrm{~cd}$ & $1.372 \mathrm{~cd}$ \\
\hline BAW 1202 & $65.92 \mathrm{de}$ & $1.440 \mathrm{de}$ & $6.325 \mathrm{~b}-\mathrm{d}$ & 9.377 b-e & 21.76 ef & $36.50 \mathrm{~cd}$ & $1.175 \mathrm{~d}$ \\
\hline CV (\%) & 6.80 & 7.74 & 7.44 & 7.88 & 8.79 & 5.81 & 6.88 \\
\hline LSD & 4.68 & 0.58 & 1.37 & 1.05 & 2.30 & 2.53 & 0.32 \\
\hline Level of significance & & $* *$ & $* *$ & $* *$ & $* *$ & $* *$ & $* *$ \\
\hline
\end{tabular}

Note: ${ }^{* *} 1 \%$ level of significant, ${ }^{*} 5 \%$ level of significant. In a vertical column, mean values having similar letter(s) are statistically identical and those having dissimilar letter(s) differ at $1 \%$ and $5 \%$ level of significance. 


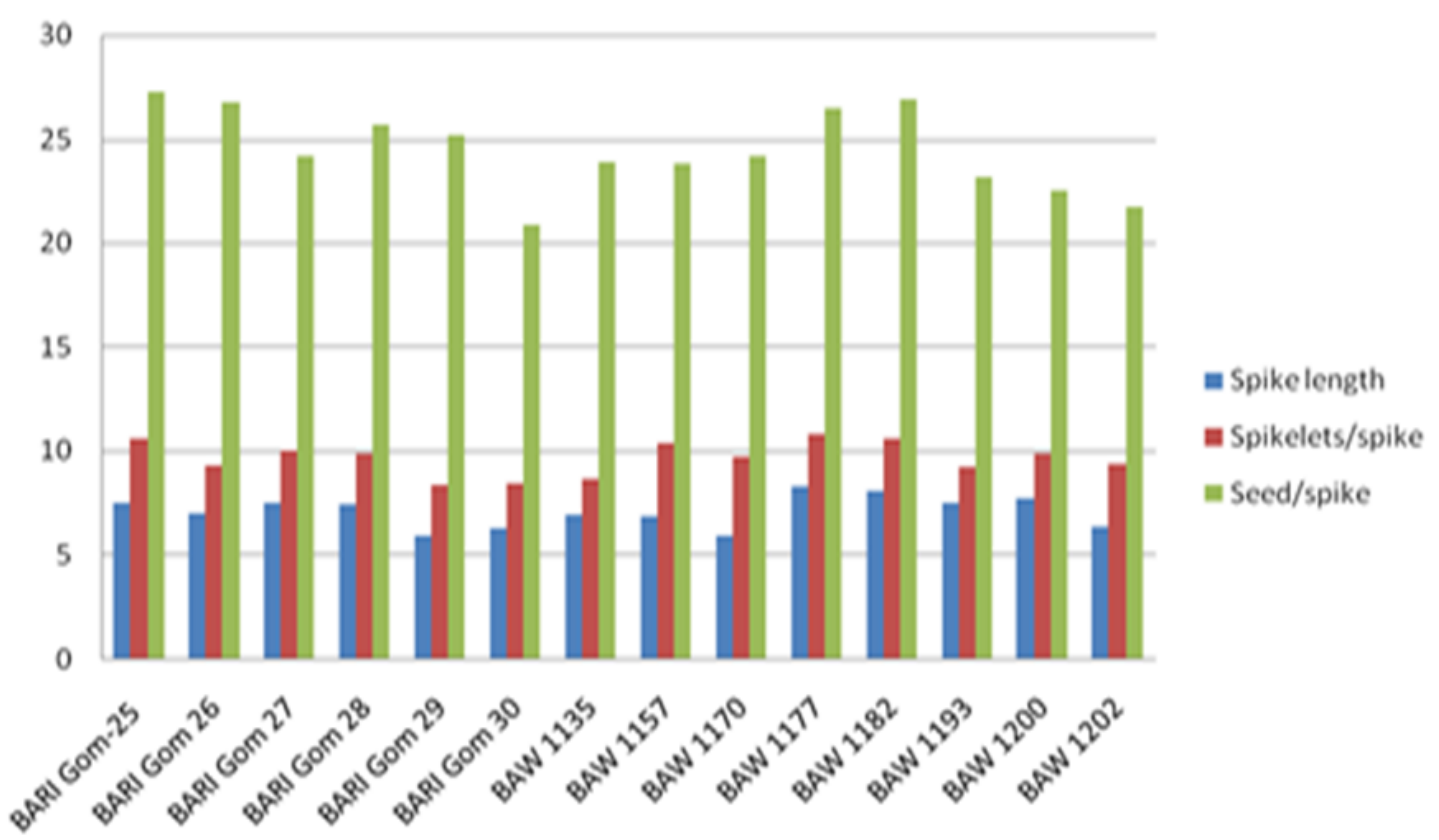

Figure 1. Bar graph showing mean Performance of wheat genotype in respect of spike length, spikelets/spike, seed/spike.

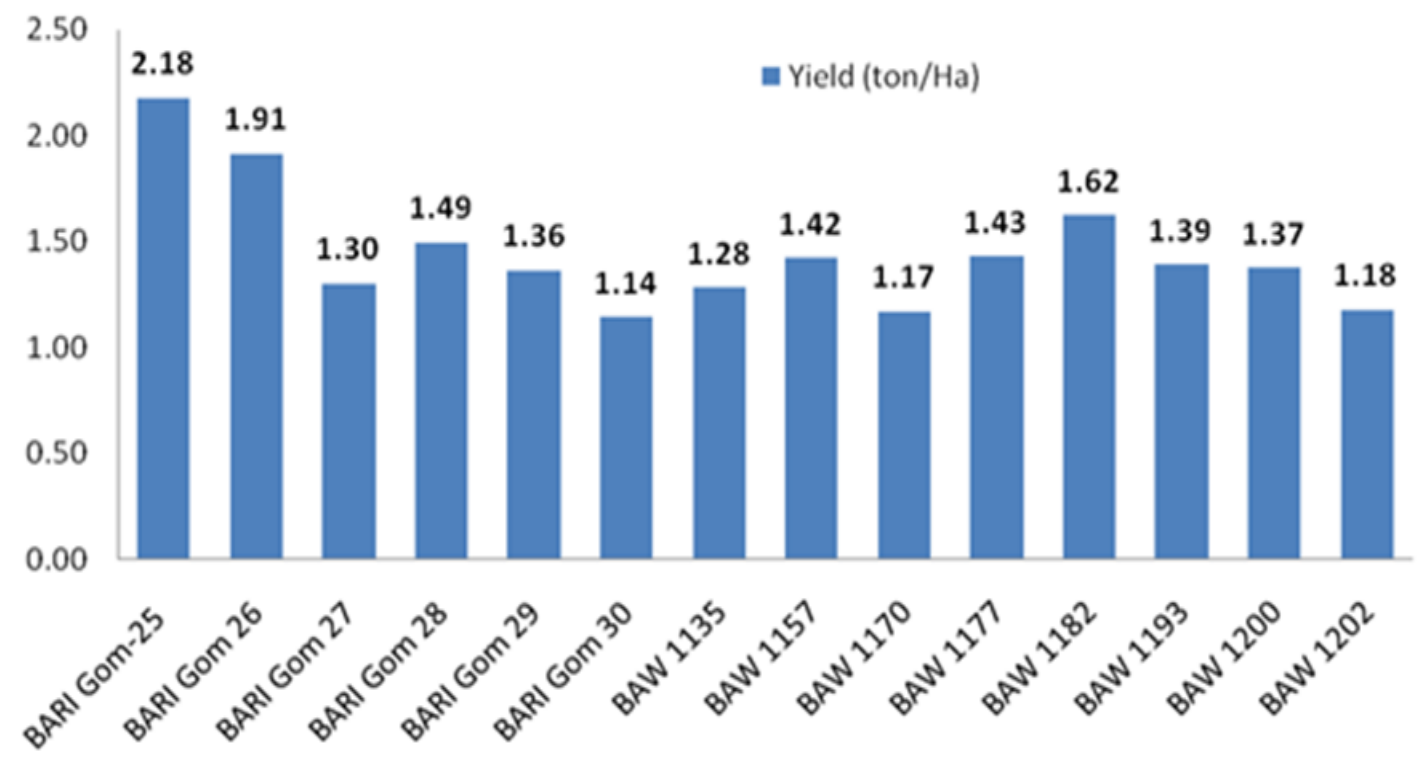

Figure 2. Performance of wheat genotype in respect of yield ( $t / h a)$.

\section{Yield (t/ha)}

Yield is the main factor in this experiment and significant variation was obtained for yield per plot. Yield of T. aestivum was ranged from 1.14 ton/ha to 2.1 ton/ha (Table 3). Maximum yield was observed in BARI Gom-25 (2.17 ton) followed by BARI Gom 26 (1.91ton). And minimum was found in BARI Gom 30 (1.14ton). Among the lines maximum yield was observed BAW 1182 (1.62 ton) and BAW 1157 (1.42 ton) and minimum yield BAW 1170 (1.17 ton) (Figure 2). Sirisampan and Zoebisch (2005) also reported similar findings earlier from their experiment. Plant heights are strongly associated with grain yield (Martin and Russell, 1984; Burak and Magoja, 1991; Singh and Dash, 2000; Umakanth et al., 2000), but Rather et al. (1999) reported the association of plant height with grain yield as non-significant.
Analysis of variance of the experimental materials

Results showed that there were significant variations among the materials for all the characters studied except plant height (Table 4). This showed the presence of considerable genetic variability among the check variety and the advance line. No significant variation was found among the replication. Flowers et al. (2004) stated that salinity tolerance is complex both genetically and physiologically with wide variation in physiological response to salinity stress. Savvas and Lenz (2000) stated that salt tolerance varieties greatly improved among plant genotypes and species.

Heritability, genetic advance and genetic advance in percentage of mean

It was found that the phenotypic co-efficient variation was higher than genotypic co-efficient of variation for all characters 
(Table 5) indicating that all interacted with the environment to some extent. Phenotypic co-efficient of variation ranged from 8.42 to 23.45 for plant height and yield of T. aestivum, respectively. High genotypic and phenotypic variance was observed in tiller per plant and yield per plant. Low magnitude of genotypic and phenotypic variance was observed in plant height, thousand seed weight, spikelet per spike, spike length, seed per spike length. High genotypic co-efficient of variation of these traits indicated the scope for effective selection. In contrast, low value of genotypic co-efficient of variation for plant height, thousand seed weight, spikelet per spike, spike length, seed per spike length of T. aestivum indicated low genetic variability and limited scope for improvement. In the present study heritability values in broad sense were high in thousand seed weight and low in seed per spikelet. High genetic advance was observed for plant height and thousand seed weight and high genetic advanced in percent mean was observed in tiller per plant and yield per plant of T. aestivum. In this study it is suggested that the heritability is due to additive gene effects and selection may be effective. Khatun et al. (2010) reported high heritability values accompanied with high genetic advance for yield and yield contributing characters in jute.

Genotypic correlation among 7 yield and yield contributing characters

Plant height of T. aestivum showed positive correlation (Table 6) with tiller per plant (0.479), spike length (0.324), spikelet per spike (0.417) and significant positive correlation with seed per spikelet (0.564), thousand seed weight (0.589), and yield per plant (0.553). Tiller per plant showed significant positive correlation with spike length (0.780), spikelet per spike (0.577), thousand seed weight (0.628), yield per plant (0.823) and positive correlation with spike length (0.324). Spike length showed significant positive correlation with spikelet per spike (0.753), seed per spikelet (0.544), spikelet per spike (0.577), and positive correlated with thousand seed weight (0.524), yield per plant (0.502), respectively. Spikelet per spike showed significant positive correlation with seed per spikelet (0.711), thousand seed weight (0.799), spike length (0.544), plant height (0.780), tiller per plant (0.564) and showed positive correlation with yield per plant (0.395). Seed per spikelet showed highly positive significant correlation with thousand seed weight (0.935) and yield per plant (0.889) spikelet per spike (0.589), tiller per plant (0.6280), plant height (0.799) and positive correlation with spike length (0.524). Thousand seed weight showed highly positive significant correlation with yield per plant (0.677). Seed per spikelet (0.889), tiller per plant (0.823), Plant height (0.553) and positive correlation with spikelet per spike (0.502) and spike length (0.395) of T. aestivum.

Phenotypic correlation among 7 yield and yield contributing characters

In this investigation (Table 7) plant height of T. aestivum showed positive correlation with tiller per plant (0.348), spike length (0.303), spikelet per spike (0.384) seed per spikelet (0.466), thousand seed weight (0.479), yield per plant (0.447). Tiller per plant showed significant positive correlation with spike length (0.577), yield per plant (0.614) and positive correlation with spikelet per spike (0.379), seed per spikelet (0.470), thousand seed weight (0.524), respectively. Spike length showed positive correlation with spikelet per spike (0.533), seed per spikelet (0.352), thousand seed weight (0.450), yield per plant (0.311), tiller per plant (0.379), plant height (0.384). Spikelet per spike showed significant positive correlation with thousand seed weight (0.542) and showed positive correlation with seed per spikelet (0.292), yield per plant (0.286), plant height (0.4660), tiller per plant (0.352), spike length (0.470). Seed per spikelet showed highly significant correlation with thousand seed weight (0.557) and yield per plant (0.611). Thousand seed weight showed positive correlation with yield per plant (0.506), spikelet per spike (0.286), spike length (0.311), plant height (0.447) and positive significant correlation with tiller per plant (0.614), seed per spikelet (0.611) of T. aestivum.

Table 4. Analysis of variance (mean squares) for different characters.

\begin{tabular}{lcccccccc}
\hline Source & d.f & $\begin{array}{c}\text { Plant height } \\
(\mathbf{c m})\end{array}$ & $\begin{array}{c}\text { Tiller/ } \\
\text { plant }\end{array}$ & $\begin{array}{c}\text { Spike } \\
\text { length }(\mathbf{c m})\end{array}$ & $\begin{array}{c}\text { Spikelets/ } \\
\text { spike }\end{array}$ & $\begin{array}{c}\text { Seed/ } \\
\text { spike }\end{array}$ & $\begin{array}{c}\text { 1000 seed } \\
\text { weight (g) }\end{array}$ & $\begin{array}{c}\text { Yield } \\
\text { ton/ha }\end{array}$ \\
\hline Replication & 3 & 83.7 & .58 & 3.41 & 16.77 & 21.24 & 2.91 & 0.82 \\
Genotype & 13 & 24.89 & .60 & 2.26 & 2.55 & 15.79 & 7.86 & 0.33 \\
Error & 39 & 10.73 & .16 & .92 & 1.05 & 4.62 & 3.13 & 0.15 \\
\hline
\end{tabular}

Table 5. Estimation heritability, genetic advance and genetic advance in percentage of mean.

\begin{tabular}{lcccccccc}
\hline Characters & $\sigma_{g}^{2}$ & $\sigma^{2}{ }_{g}$ & $\sigma^{2}{ }_{p}$ & PCV & GCV & $h^{2}{ }_{b}(\%)$ & GA & $\%$ GA \\
\hline Plant height & 22.327 & 10.736 & 33.063 & 8.42 & 6.92 & 67.53 & 8.00 \\
Tiller per plant & 0.135 & 0.065 & 0.200 & 22.34 & 18.35 & 67.48 & 0.62 & 31.05 \\
Spike length & 0.498 & 0.277 & 0.774 & 12.44 & 9.98 & 64.26 & 1.16 & 16.47 \\
Spikelet per spike & 0.496 & 0.578 & 1.074 & 10.75 & 7.31 & 46.20 & 0.99 & 10.23 \\
Seed per spikelet & 2.792 & 4.625 & 7.417 & 11.13 & 6.83 & 37.64 & 2.11 & 8.63 \\
Thousand seed weight & 11.681 & 1.136 & 12.817 & 9.45 & 9.02 & 91.14 & 6.72 & 17.74 \\
Yield per plant & 0.003 & 0.002 & 0.005 & 23.45 & 18.90 & 64.91 & 0.09 & 31.36 \\
\hline
\end{tabular}


Table 6. Genotypic correlation among 7 yield and yield contributing characters studied in 14 wheat genotypes.

\begin{tabular}{|c|c|c|c|c|c|c|}
\hline Characters & $\begin{array}{c}\text { Tiller per } \\
\text { plant }\end{array}$ & Spike length & $\begin{array}{l}\text { Spikelet per } \\
\text { spike }\end{array}$ & $\begin{array}{l}\text { Seed per } \\
\text { spike }\end{array}$ & $\begin{array}{c}\text { Thousand } \\
\text { seed weight }\end{array}$ & $\begin{array}{c}\text { Yield per } \\
\text { plant }\end{array}$ \\
\hline Plant height & 0.479 & 0.324 & 0.417 & $0.564^{*}$ & $0.589^{*}$ & $0.553^{*}$ \\
\hline Tiller per plant & & $0.780^{* *}$ & $0.577^{*}$ & $0.780^{* *}$ & $0.628^{*}$ & $0.823^{* *}$ \\
\hline Spike length & & & $0.753^{* *}$ & $0.544^{*}$ & 0.524 & 0.502 \\
\hline Spikelet per spike & & & & $0.711^{* *}$ & $0.799^{* *}$ & 0.395 \\
\hline Seed per spikelet & & & & & $0.935^{* *}$ & $0.889^{* *}$ \\
\hline Thousand seed weight & & & & & & $0.677^{* *}$ \\
\hline
\end{tabular}

Table 7. Phenotypic correlation among 7 yield and yield contributing characters studied in 14 wheat genotypes.

\begin{tabular}{|c|c|c|c|c|c|c|}
\hline Characters & $\begin{array}{l}\text { Tiller per } \\
\text { plant }\end{array}$ & Spike length & $\begin{array}{l}\text { Spikelet per } \\
\text { spike }\end{array}$ & $\begin{array}{c}\text { Seed per spike- } \\
\text { let }\end{array}$ & $\begin{array}{l}\text { Thousand } \\
\text { seed weight }\end{array}$ & $\begin{array}{l}\text { Yield per } \\
\text { plant }\end{array}$ \\
\hline Plant height & 0.348 & 0.303 & 0.384 & 0.466 & 0.479 & 0.447 \\
\hline Tiller per plant & & $0.577^{*}$ & 0.379 & 0.470 & 0.524 & $0.614^{*}$ \\
\hline Spike length & & & 0.533 & 0.352 & 0.450 & 0.311 \\
\hline Spikelet per spike & & & & 0.292 & $0.542^{*}$ & 0.286 \\
\hline Seed per spikelet & & & & & $0.557^{*}$ & $0.611^{*}$ \\
\hline Thousand seed weight & & & & & & 0.506 \\
\hline
\end{tabular}

Conclusion

Genetics analysis of the selected genotypes of T. aestivum to identify tolerant genotypes that may sustain a reasonable yield on salt affected soil. Significant variation for yield and yield contributing characters indicate the presence of genetic variations among the genotypes for these characters except plant height. Among all lines of wheat BAW 1182, BAW 1177 showed higher value in all character. Genotypic and phenotypic co-efficient of variation was low for almost all of the characters studied in the present study. The phenotypic co-efficient of variation (PCV) were higher than their corresponding genotypic co-efficient of variation (GCV) for all the characters studied indicating that they all interacted with the environment to some intent. Phenotypic co-efficient of variation ranged from 8.42 to 23.45 for plant height and yield respectively. All of the characters exhibited moderate to high heritability in broad sense $\left(\mathrm{h}^{2}{ }_{\mathrm{b}}\right)$ coupled with a wide range of genetic advance and genetic advance in percentage of mean. Heritability ranged from 37.64 to 91.14 for seed per spike and thousand seed weight, respectively. In case of character association, yield had a significant positive correlation with spike length, spikelet per spike, seed per spike, thousand seed weight. On the other hand, yield was found to display a positive relationship with tiller per plant. Yield ranged from 1.14 ton/ha to 2.1 ton/ha. The present research work clearly demonstrated that based on field performance considering yield the genotypes BARI Gom 25 and BARI Gom 26 is best and other some genotypes BAW 1182, BAW 1177, respectively showed their most effective performance on saline soil. Overall yield performances of all the genotypes were very low it is due to showering at germination and flowering stage. Salinity of the trail plots increased with time and it ranges 2.5 to 10.3 in the whole growing period. However, the present research work clearly demonstrated that based on field performance considering yield the genotypes BARI Gom 25 and BARI Gom 26 is best and other some lines BAW 1182, BAW 1177, respectively showed their most effective performance on saline soil.

\section{ACKNOWLEDGEMENT}

The authors desire to acknowledge Department of Genetics and Plant Breeding, Patuakhali Science and Technology University, Patuakhali, Bangladesh for providing necessary facilities and valuable support to accomplish this research work.

\section{Conflict of interest}

The authors declare there are no conflicts of interest.

Open Access: This is an open access article distributed under the terms of the Creative Commons Attribution 4.0 License, which permits unrestricted use, distribution, and reproduction in any medium, provided the original author(s) if the sources are credited.

\section{REFERENCES}

Akhtar, M.Z., Khan, M.A., Ahmad, M.A. (2001). Evaluation of wheat (Triticum aestivum L.) Varieties for their potential grain yield under the agro-ecological conditions of DI Khan. Journal of Biological Sciences, 1, 568-570, https://scialert.net/abstract/?doi=jbs.2001.568.570

Ashraf, M. and Wu, L. (1994). Breeding for salinity, tolerance in plants. CRE Critical Reviews in Plant Sciences, 13:17-42, https://doi.org/10.1080/07352689409701906

Braun, H. J., Atlin, G. and Payne, T. (2010). Multi-location testing as a tool to identify plant response to global climate change. In: Reynolds CRP (Ed.). Climate Change and Crop Production, CABI, London, UK., https://www.cabdirect.org/cabdirect/ abstract/20103205645

Burak, R. and Magoja, J.L. (1991). Yield and yield components of full-sib and half-sib families derived from perennial teosinte introgression population. MaizeGenet. Corp Newslett., 7: 431-76.

Chowdhury, N.K. and Islam, M.A. (1993). Production and uses Maize (In Bengali). Published By on Farm Research Division Bangladesh Agricultural Institute Joydebpur, Gazipur. pp. 1-189. 
El-Shouny, K.A., El-Baguory, O.H., Ibrahim, K.I.M. and Al-Ahmad, S.A. (2005). Correlation and path coefficient analysis in four yellow maize crosses under two planting dates. Arab Universities Journal of Agricultural Sciences, 13(2): 327-339, https:// www.cabdirect.org/cabdirect/abstract/20053077121

FAOSTAT. (2010) Data, 2007, Food and Agricultural commodities production, Rome, Italy. Available online at: http://faostat.fao.org

Flowers and T.J. (2004). Improving crop salt tolerance. Journal of Experimental Botany, $55 \quad$ (396): 307-319, https://doi.org/10.1093/jxb/erh003

Genc, Y., Mc.Donald G.K. and Tester, M. (2007). Reassessment of tissue $\mathrm{Na}+$ concentration as a criterion for salinity tolerance in bread wheat. Plant, Cell \& Environment, 30: 14861498, https://doi.org/10.1111/j.1365-3040.2007.01726.x

Gomez, K.A. and Gomez, A. A. (1984). Statistical Procedure for Agricultural Research. Second Edition. A Willey Inter Science Publication, John Wiley and Sons, New York. pp. 680

Houshmand, S., Arzani, A., Maibody, S.A.M. and Feizi, M. (2005). Evaluation of salt-tolerant genotypes of durum wheat derived from in vitro and field experiments. Field Crops Research, 91(2-3): 345-354, https://doi.org/10.1016/j.fcr.2004.08.004

IFPRI, International Food Policy Research Institute (1997). Wheat production in Bangladesh: Technological, Economic, and Policy Issues.

Iftekhar and Islam (2004). Ecological characteristics of the coastal zone, Sundarban coastal Island and Saline Belt. In: Environmental Aspects of Surface Water systems of Bangladesh.Vol.2.UPL, Dhaka, Bangladesh, pp. 66-101.

Khatun, R., Sarker, R.H. and Sobhan, M.A. (2010). Diallel analysis of seven quantitative traits in deshi jute (Corchorus capsularis I.). Bangladesh Journal of Botany, 39(2): 137-141.

Martin., M.J. and Russel. A.W. (1984). Correlation response of yield and other agronomic traits to recurrent selection for stalk quality in maize synthetics. Crop Science, 24(4): 746-50, https://doi.org/10.2135/ cropsci1984.0011183X002400040028x

Mohammedein, B. Alhussein and Atif, E. Idris (2017). Correlation and path analysis of grain yield components in some maize (Zea mays L.) genotypes. International Journal of Advanced Research and Publications, 1(1): 79-82.

Moursi, M.A., Oraby, F.T., Zeidan, E.M. and Nigem, S.A. (1975). The contribution effect of some yield components to the grain yield of maize (Zea mays L.). Zagazig Journal of Agriculture Research, 2 (1): 143-153, http://agris.fao.org/agrissearch/search.do?recordID=EG19780255557

Norlyn, and Epstein, J. (1984). Breeding salt tolerance crop plants. In genetic Engineering of Osmoregulation. D.W. Rings, R.C. Valentine and A. Hollaender (ed). Basic Life Science, 14,293-309, Plenum Press, New York.

Rather, A.G., Sheikh., F. A. and Wani, S. A. (1999). Variability and correlation studies in maize (Zea mays L. ) under rainfed conditions. Advances in Plant Cciences,12: 539-542.

Richards, R.A., Dennett, C.W., Qualset, C.O., Epstein, E., Norlyn, J.D. and Winslow, M.D. (1987). Variation in yield of grain and biomass in wheat, barley and triticale in a salt affected field. Field Crop Research, 15(3-4): 277-287, https://doi.org/10.1016/0378-4290(87)90017-7

Richards. R.A. (1983). Should selection for yield in saline conditions be made on saline or non-saline soils? Euphytica, 32: 431, https://doi.org/10.1007/BF00021452

Savvas, D. and Lenz, F. (2000). Effect of $\mathrm{NaCl}$ or nutrient-induce salinity on growth, yield and composition of eggplants grown in rock wool. Scientia Horticulturae, 84(1-2): 37-47, https://doi.org/10.1016/S0304-4238(99)00117-X

Singh, J.M. and Dash, B. (2000). Analysis of genetic variability and character association in maize. African Crop Science Journal, 5: 1-8.

Singh, R.K., Chaudhury, B.D. (1985). Biometrical Methods in Quantitative Genetic Analysis (rev. edition). Kalyani Publisher, New Delhi, India.

Sirisampan, S. and Zoebisch, M.A. (2005). Variety and cultivation-practice influences on the growth characteristics and yield of maize (Zea mays) under drought stress at flowering. Journal of Agriculture and Rural Development in Tropics and Subtropics, 106(1): 15-27, https://www.jarts.info/index.php/jarts/article/view/78

Toker, C. and Cagirgan, M.I. (2004). The use of phenotypic correlations and factor analysis in determining characters for grain yield selection in chickpea (Cicer arietinum L.). Hereditas, 140: 226-228, https://onlinelibrary.wiley.com/ doi/pdf/10.1111/j.1601-5223.2004.01781.x

Umakanth, A.V., Satyanarayana, E. and Nagesh Kumar, M.V. (2000). Correlation and heritability studies in Ashwini maize composite. Annals of Agricultural Research, 21(3): 228 -230, https://www.cabdirect.org/cabdirect/ abstract/20003015785 